\title{
Beyond Disciplines: \\ Providing Outreach to Underserved Groups by Demographic
}

\begin{abstract}
As more students, faculty, and staff from traditionally underrepresented groups enter universities and colleges, academic libraries must find ways to reach out to these groups in order to better meet their unique educational needs. In this article, librarians from two large public universities describe how they used data about their communities to determine which underserved groups might need additional outreach, and then marketed library tools and services to student veterans, students with disabilities, and lesbian, gay, bisexual, and transgender (LGBT) students.
\end{abstract}

\section{Introduction}

Given the ever-increasing need to optimize dwindling resources in libraries, scholarly conversations about the best strategies for reaching out to multiple user groups have become ubiquitous. In an effort to maximize investments of time and money, outreach to underserved groups may be overlooked. Developing strong outreach campaigns for underserved groups is especially important given the continued growth of minority enrollment in higher education (Puente, Gray and Agnew 2009, p. 31). However, determining which underserved groups would benefit most from outreach on a particular campus and then developing a systematic and scalable outreach plan requires careful thought. In this article, we describe how we used a variety of publicly-available sources of demographic data to learn more about our student body and to identify underserved populations on our campuses that would benefit from additional outreach efforts.

The American Library Association's (ALA) Office for Literacy and Outreach Services (OLOS) has identified specific underserved groups toward which to direct its efforts, including LGBT persons and people with disabilities, among others. The ALA (2015) describes these efforts as "[focusing] attention 
on services that are inclusive of traditionally underserved populations, including new and non-readers, people geographically isolated, people with disabilities, rural and urban poor people, and people generally discriminated against based on race, ethnicity, sexual orientation, age, language and social class" (para. 1). Based on this definition, we determined that the groups we considered to be underserved on our campuses and toward which we would direct our outreach efforts would be those who may experience barriers to using library services at our institutions. Although there are a number of groups that meet this definition, we will describe how we used available data to select three groups to target for outreach: LGBT students, student veterans, and students with disabilities.

\section{Literature Review}

Importance of Outreach

In order to be clear on what constitutes outreach, it helps to define our terms. Outreach is distinct from marketing, which has a different set of objectives. Marketing, for the purposes of this paper, is the combined set of strategies used to communicate with users about library offerings. Outreach, which often includes marketing, additionally involves building a long-term relationship with user groups and requires partnerships or activities outside of the library building (Cummings, 2007, 287).

It also helps to understand the general models of outreach that often inform the variety of outreach activities that are common in libraries. One of the most common strategies for traditional outreach is the liaison model, which assigns librarians to specific subsets of users across campus, usually academic departments (Rudin, 2008, p. 68). Having departmental liaisons is a great way to spread the work of doing outreach among multiple librarians. However, in many cases, this kind of outreach may not reach those students and other library users who are not strongly affiliated with an academic department (Love and Edwards, 2009). Many liaison librarians are also responsible for other duties associated with the position, such as collection development, and they may have limited time to leverage departmental relationships for outreach opportunities. 
Creating service points around the campus in order to reach patrons who do not typically come to the physical library, also called "outpost librarianship," is another common outreach model (Rudin, 2008). Examples of this form of outreach include dorm outreach (e.g. Riehle and Witt, 2009; Long; 2011) or regular office hours in the student union or other buildings on campus. Although this model can be successful, it may require significant expenditure of time and effort to maintain a satellite location on a consistent basis. In addition, outposts are in many cases a passive kind of outreach, requiring students and other community members to take the initiative to visit the librarian, which can discourage those who are unfamiliar with library services.

Kesselman and Watstein (2009) describe different elements related to embedded librarianship, another way in which librarians are doing outreach: "embedded librarians are, first and foremost, integrated into their settings, be they traditional or nontraditional. In academic settings, embedded librarians are in collaborative learning environments. They are on research teams. They are in academic departments. They are co-instructors in the classroom and in the online classroom" (387). Embedded librarians have unique opportunities to partner with the departments in which they are embedded in order to draw in users, but may struggle to reach students who do not spend a lot of time in their departments.

The common thread among most models is the reliance on relationships with other academic entities, and most often academic departments. Although there are examples in the literature of the benefits of collaborating with student services, multicultural student centers, or other established campus units (e.g. Swartz, Carlisle and Uyeki, 2007; Walter, 2005; Love and Edwards, 2009), many of these relationships may not reach students who do not already have strong affiliations and campus ties. In an attempt to reach these loosely-affiliated students, we wanted to develop a suite of outreach strategies based upon information uncovered in an analysis of available demographic data. 
Switzer (2008) notes that libraries play an essential role in making college and university campuses inclusive of multiple underrepresented students, calling on libraries to develop long-term strategies to better serve these groups. Many scholars have begun to explore the unique challenges that LGBT students, student veterans, and students with disabilities face in feeling comfortable on campus and in the library. Mehra and Braquet (2011) show that libraries play a key role in reducing the marginalization that LGBT people may feel and supporting LGBT students as they seek information about sharing their identities with family and friends. Naidoo (2014) also highlights the importance of access to information for LGBT youth and their families. LGBT students are an invisible minority, often not visible unless they self-identify, which can be a challenge in assessing both the size of the population and their potential needs. However, Greenblatt (2010) also provides several ways that supportive practices can be put in place throughout libraries to better support LGBT students.

Likewise, libraries play a key role in supporting student veterans, a growing demographic. Sojdehei (2009) explains that "U.S. colleges and universities have witnessed a monumental increase in the number of veterans using their Post-9/11 GI Bill benefits, with numbers totaling 555,329 in 2011" (p. 537). As Phelps (2015) notes, veterans may face challenges that other students do not, including trauma from participating in war, and need to be welcomed by libraries. Libraries can play a key role in helping veterans reorient to civilian life by offering special programming, like entrepreneurial support (Hoppenfeld, Wyckoff, Henson, Mayotte, \& Kirkwood, 2013), writing workshops (Hartman and Baumgartner, 2011), or by helping veterans find health and benefits information (Evans, 2012). Students with disabilities may also need specialized outreach to get them to use library services. Samson (2011) highlights the need for libraries to improve outreach and service to patrons with disabilities, at least half of whom may not reach out for help to campus disability service offices. Several authors have noted that libraries can play a role in supporting patrons who use assistive technology to 
access library resources by providing both the technology and the training to use it (e.g. Bonnici, Maata and Wells, 2009; Saar and Arthur-Okor, 2013; Falloon, 2015; Remy and Seaman, 2014).

\section{Using Data to Highlight Changing Demographics}

The first step toward developing outreach campaigns for underserved students was to identify which populations were present on our campuses and who were not otherwise targeted by outreach campaigns. We used publicly-available data from the University of Utah (U of U), where both authors were working at the time, to identify that LGBT students, student veterans, and students with disabilities were three of the campus groups that likely needed outreach. Later, Sarah used similar data from her new institution, Texas A\&M University (TAMU), in order to determine whether to pursue her outreach efforts with student veterans on a new campus.

When looking for data, we took advantage of several sources of publicly-available demographic information. Publicly-available campus sources of demographic information provide a crucial foundation for understanding the unique demographics on an individual campus. The $U$ of $U$ Office for Budget and Institutional Analysis (OBIA), which collects student data and then publishes publicly-available campus profiles, proved to be an excellent source for identifying which potentially underserved groups had substantial numbers on the $U$ of $U$ campus. For instance, $30 \%$ of degree seeking undergraduates at the $\mathrm{U}$ of $\mathrm{U}$ listed their race as something other than Non-White/Hispanic in 2014-15 surveys done by OBIA (2015a). This campus data can provide unexpected insights into the student body, including facets such as the number of in-state versus out-of-state students, percentage of students living in dormitories versus off-campus, and even the number of students participating in fraternities or sororities (OBIA, 2015b).

The caveat to this type of data collection, however, is that there are many kinds of demographic information that are not collected by colleges and universities. In order to maintain privacy, colleges and 
universities in the United States often do not collect information about the number of LGBT students or students with disabilities, and even when this data is collected it may not be made publicly available. Therefore, examining these populations often requires using evidence from larger national, state, and community trends.

For example, although the numbers of students who identify as LGBT or as having a disability on the $U$ of $U$ campus is not included in publicly-available reports, national figures suggest that somewhere 3.4 and 8 percent of people identify as gay lesbian, or bisexual (Gates and Newport, 2012; Herbenick, Reece, Schick, Sanders, Dodge, and Fortenberry, 2010). Similarly, between .5\% and 2\% of Americans identify as transgender (Gates, 2011) and approximately 19\% of Americans have a disability (Brault, 2008). Although we don't know how these demographics are represented specifically on the $U$ of $U$ or TAMU campuses, we can make the assumption that such substantial populations nationally will be represented in significant numbers in our students, although the representation may vary between communities based on local factors such as access to social services and political climate.

By reviewing the data we obtained through campus and government sources, as well as from existing library user surveys, we were able to develop a helpful, if imperfect, picture of the underserved populations we could expect to find on our campuses. Based upon our new understanding of the campus communities, we were able to identify three of the student populations expected to be present on our campus in significant numbers and which could likely benefit from increased library outreach. Based on the data we described above, we determined that two of the OLOS-identified underserved populations were likely to be present on the $U$ of $U$ campus were students with disabilities and LGBT students. Additional research determined that there were a significant number of student veterans both at the $U$ of $U$, where the campus Veterans Support Center reported enrollment of 968 student veterans in Fall 2015 (Veterans Support Center, 2015), and at TAMU, where over 1,100 veterans were enrolled in 
Fall 2014 (Texas A\&M, 2015). Because both universities had such substantial populations of student veterans, we felt that these groups could also benefit from additional library outreach strategies.

\section{Outreach Strategies}

Successful outreach efforts need to be targeted to demographics present on individual campuses or communities, and outreach campaigns must be designed with time constraints in mind. Carter and Seaman (2011) note, "while many libraries participate in different types of outreach, they often do so in informal and ad hoc ways without the benefit of systematic and well thought out outreach programs" (p. 168). Although short-term outreach strategies are absolutely necessary to respond to community changes in an agile way, it is also important to utilize a set of formal strategies to ensure outreach efforts are sustainable and scalable. When devising outreach strategies for targeting underserved populations, we opted to employ both active and passive outreach strategies. This method ensured that our outreach efforts did not outstrip the amount of time that we had available and allowed us to scale our strategies to better assist other underserved populations on our campus. We also worked to create outreach relationships that were scalable and sustainable over time.

\section{Passive Outreach Strategies}

Passive outreach strategies, which ask students to make the first step to contact a librarian, are commonly used to reach student populations. Cannady, King, and Blendinger (2012) used several passive outreach strategies, including LibGuides, study halls, and office hours, to reach adult learners. Passive outreach strategies require patrons to initiate contact and therefore it can be challenging to get patrons from marginalized groups to respond to these types of effort. However, we chose to use some passive outreach strategies because they scale well to large student populations without overwhelming librarians' limited available time. In addition to LibGuides aimed at our target populations and office hours in the $U$ of $U$ Center for Disability Services and Veterans Support Center, we employed the passive 
outreach strategy of creating displays to bring attention to our target student populations in order to help members of these groups recognize themselves as potential library patrons.

Fabian, D'aniello, Tysick, and Moring (2003) note that "to have a significant educational and public relations impact, exhibits must demonstrate sensitivity to the interests of the local environment, a meaningful understanding of the topic, and a compelling technical execution" (p.45). We worked with members of our target populations in an effort to ensure that library displays accurately and sensitively represented their experiences. For example, Sarah solicited photographs from student veterans that represented their military service and then composed them into a display to inform and educate the campus about the experience of their veteran classmates. This display, which was available throughout the month of November in order to coincide with Veterans Day, was very successful in drawing attention from students, student veterans, and the larger community. Sarah followed up on this success by soliciting, both on her own and with help from campus partners, student photographs that specifically highlighted the deployment experiences of women veterans. This strategy allowed us to connect with student veterans and the general student body directly as well as through intermediaries.

Another passive outreach strategy involved working with local media to highlight library services for target populations. For example, Sarah participated in a feature on women veterans for a local newspaper publication. This feature, which discussed Sarah's own experiences as a military veteran, was then promoted by both the Marriott Library and the campus Veterans Support Center in order to inform student veterans that there was a veteran/librarian available to work with them. Similarly, Lorelei worked with an intern to create an exhibit highlighting LGBT history in the state and then promoted the exhibit via a radio spot, an online splash page, and a newspaper article. The library also hosted an interview of an important figure in the state's LGBT history, which led to a news story highlighting both the exhibit and the interview. These strategies were intended to help underserved students recognize the library as a campus entity invested in their presence on campus and in the library, and to help them 
feel welcome in the library. These outreach efforts, while initially time-consuming, scaled very well in order to reach a potentially large number of students and community members.

\section{Active Outreach Strategies}

While active outreach strategies are not as scalable as passive outreach strategies, they are a crucial element toward building strong relationships with underserved groups. It is through active outreach that personal relationships develop. Indeed, Love and Edwards (2009) suggest starting collaborations based on personal relationships:

The key to collaboration is turning a personal relationship into an organizational partnership. To do so, the initial contact must be based upon known facts of the individual (i.e. what is their expertise, what projects and initiatives do they lead), or at the very least, the organization. Referencing prior conversations or introductions with the individual can always break the ice. However, all too often, such a relationship will not have existed previously and doing research prior to the conversation will be informative and beneficial. (p. 24)

In order to ensure that our active outreach efforts were successful, we chose to work with underserved student communities in which we held significant personal interest, thus facilitating the formation of strong personal relationships with both individual members of the student community and with related organizations. For example, Sarah is an Army veteran and was able to use her military experience and personal interest in veterans' issues to help build relationships, first with the $U$ of $U$ Veterans Support Center and now with the TAMU Veteran Resource and Support Center, as well as with other veteranrelated organizations on campus and in the community.

One active outreach strategy we employed was to build relationships directly with students in our target demographic areas. For instance, Lorelei held informal interviews with several students with disabilities and used the results to suggest library space modifications, such as moving the library's 
adjustable height desks to more easily accessible locations. We built similar relationships by participating in committees that incorporated students such as the $U$ of $U$ Pride Planning Committee, which puts together programming to celebrate LGBT people. This type of activity allowed us to reach students in OLOS-identified underserved demographic groups who may not affiliate strongly with other campus institutions.

In addition to this direct approach, one of the most effective active outreach strategies that we employed was working closely with external partners, including the Utah Pride Center, the $\mathrm{U}$ of $\mathrm{U}$ Veterans Support Center and the TAMU Veteran Resource and Support Center, the $U$ of $U$ Center for Disability Services, and the U of U LGBT Resource Center. These campus and local partners already have strong relationships with the underserved groups that we were targeting, and working in partnership with these groups provides us with insight into our target populations and effective outreach strategies. For example, Lorelei reached out to both the U of U LGBT Resource Center and the Utah Pride Center when it decided to target LGBT students as an underserved group. Through these connections, we were able to find outreach opportunities and bring new patrons into the library, such as when Lorelei hosted a tour of the Fine Arts Library collections for an LGBT social group in the area. She was also able to work with a team of interested librarians who received a grant in order to build a display highlighting local LGBT history, which brought members of the campus and the community into the library over a period of several weeks. These types of events helped signal the library's interest in and support for a marginalized population on campus, and was intended to help LGBT students and members of the community feel welcome in the library. Another successful partnership example was the close relationship she helped develop with the campus Center for Disability Services. She invited members of their staff to the library to evaluate the accessibility of its services and identify areas where they might improve. This partnership led to a number of service improvements aimed at removing barriers for students with impairments. 
The close partnerships we developed with external partners also led to unexpected outreach opportunities. For example, the Marriott Library was able to help sponsor events such as the 2013 panel discussion Lionesses: Voices of Military Women. This event, cosponsored by the $\mathrm{U}$ of $\mathrm{U}$ Marriott Library and Veterans Support Center, featured university-affiliated women veterans discussing their experiences serving in the military. The event also drew other local partners, including representatives from the VA, the VA Salt Lake City Women Veterans Program and members of the planning committee for the Fort Douglas Military Museum Women's Memorial. The Lionesses event, like the library's veteran-oriented displays, was aimed at providing $U$ of $U$ veterans with a platform they could use to talk about their own military experiences and at giving students, staff, and faculty an opportunity to learn about the experiences of the veterans among them. This type of event, like the other active outreach strategies we employed, required a considerable time commitment but helped us become known on campus as advocates for our selected populations.

\section{Summary and Analysis}

As a result of our strategic outreach efforts, as well as those of our colleagues, we have created opportunities to connect with potentially-significant underserved communities. Over time, the partnering organizations we targeted have come to consider the library a collaborator in their efforts toward helping these underserved communities succeed on our campuses. Lorelei has developed close relationships with U of U LGBT Resource Center and the Center for Disability Services and these relationships have led to invitations for the Marriott Library to participate in events, such as scholarship and faculty celebrations. Similarly, Sarah's outreach to student veterans first at the $U$ of $U$ and later at TAMU has led to the inclusion of the library in a number of campus veterans events. For example, the TAMU Veteran Resource and Support Center now includes the library in its "Vet Camp" event welcoming incoming student veterans each semester. They have also included Sarah as a member of the Aggie Vet Network, an extensive and active list of contacts to whom they refer student veterans for 
help. These partnerships enhance our libraries' ability to provide outreach to underserved students and help them achieve academic success.

We suggest that other library employees who are interested in reaching out to underserved groups will benefit from exploring their campus demographics and developing strategies for reaching out to the underserved groups on their campus. Demographic information can serve as a starting point to help each library identify community members who could benefit from library support but may not regularly use the library. For example, although the authors chose to target student veterans, students with disabilities, and LGBT students, the $U$ of $U$ Marriott Library has also begun outreach to students with children, another substantial population on the $U$ of $U$ campus with potential barriers to using the library. In addition, utilizing both passive and active strategies, such as creating displays, connecting to the media, and cohosting events with external partners enable libraries to balance impact with cost in both time and resources. Although outreach can be time consuming, our experiences, as well as the experiences of other libraries, demonstrate its impact. Outreach to underserved groups in particular is an important way to make library resources accessible to those who might not otherwise be exposed to traditional outreach strategies. We would suggest similar approaches as a part of any library's outreach plan. By regularly reviewing demographic information, librarians can ensure that their outreach efforts are timely and systematic, rather than sporadic.

\section{References}

American Library Association (2015). Office for Literacy and Outreach Services (OLOS). Retrieved from http://www.ala.org/offices/olos

Bonnici, L. J., Maatta, S. L., \& Wells, M. K. (2009). US national accessibility survey: Librarians serving patrons with disabilities. New Library World, 110(11/12), 512-528. doi:

$\underline{10.1108 / 03074800911007532}$ 
Brault M. W. (2008). Americans with disabilities, 2005. Current population reports. Washington, DC: U.S: Census Bureau. Retrieved from http://accessinsights.com/p70-117.pdf

Cannady, R. E., King, S. B., \& Blendinger, J. G. (2012). Proactive outreach to adult students: A department and library collaborative effort. The Reference Librarian, 53(2), 156-169. doi: $10.1080 / 02763877.2011 .608603$

Carter, T. M., \& Seaman, P. (2011). The management and support of outreach in academic libraries. Reference \& User Services Quarterly, 51(2), 163-171.

Cummings, L. U. (2007). Bursting out of the box: Outreach to the millennial generation through student services programs. Reference Services Review, 35(2), 285-295. doi:

$10.1108 / 00907320710749191$

Evans, K. (2012). Serving those who served us: Resources for active duty soldiers and veterans. College \& Research Libraries News, 73(8), 470-480.

Fabian, C. A., D’aniello, C., Tysick, C., \& Morin, M. (2003). Multiple models for library outreach initiatives. The Reference Librarian, 39(82), 39-55. doi: 10.1300/J120v39n82_04

Falloon, K. (2015). A case study in practice: Providing accessibility for person with disabilites at the College of Staten Island Library. In P. T. Jaeger \& J. C. Bertot (Eds.), Accessibility for persons with disabilities and the inclusive future of libraries (Vol. 40, pp. 89-107): Emerald Group Publishing.

Gates, Gary J. (2011). How Many People are Lesbian, Gay, Bisexual and Transgender? UCLA: The Williams Institute. Retrieved from: https://escholarship.org/uc/item/09h684x2

Gates, G. J., \& Newport, F. (2012, October 18).Special report: 3.4\% of U.S. adults identify as LGBT. Gallup. Retrieved from http://www.gallup.com/poll/158066/special-report-adults-identifylgbt.aspx

Greenblatt, E. (2010). Serving LGBTIQ Library and Archives Users: Essays on Outreach, Service, Collections and Access, Jefferson, NC: McFarland 
Hartman, A., \& Baumgartner, H. (2011). Helping warriors unleash the power of the pen: A library writing workshop helps veterans share their experiences. American Libraries, 42(11-12), 38-41.

Herbenick, D., Reece, M., Schick, V., Sanders, S., Dodge, B., \& Fortenberry, J. D. (2010). Sexual behavior in the United States: Results from a national probability sample of men and women ages 14 to 94. Journal of Sexual Medicine 7(Suppl. 5), 255-265.

Hoppenfeld, J., Wyckoff, T., Henson, J. A. J., Mayotte, J. N., \& Kirkwood, H. P. (2013). Librarians and the entrepreneurship bootcamp for veterans: Helping disabled veterans with business research. Journal of Business \& Finance Librarianship, 18, 293-308. doi:10.1080/08963568.2013.825227

Kesselman, M. A., \& Watstein, S. B. (2009). Creating opportunities: Embedded librarians. Journal of Library Administration, 49(4), 383-400. doi: 10.1080/01930820902832538

Long, D. (2011). Embedded right where the students live: A librarian in the residence halls. In K. Calkins and C. Knevild (Eds.), Embedded librarians: Moving beyond one-shot instruction (pp. 199-211). Chicago: Association of College \& Research Libraries.

Love, E., \& Edwards, M. B. (2009). Forging inroads between libraries and academic, multicultural and student services. Reference Services Review, 37(1), 20-29. doi: 10.1108/00907320910934968

Mehra, B., \& Braquet, D. (2011). Progressive LGBTQ reference: coming out in the 21st century. Reference Servjces Review, 39, 401-422 doi: $\underline{10.1108 / 00907321111161403}$

Naidoo, J. C. (2014). Reaching out to LGBTQ youth. In C. S. Kerol Harrod (Ed.), Library youth outreach: 26 ways to connect with children, young adults and their families (pp. 84-92). Jefferson, NC: McFarland.

OBIA (Office of Budgets and Institutional Analysis) (2015a). B2: Enrollment by racial/ethnic category. [Table] Retrieved from http://www.obia.utah.edu OBIA (Office of Budgets and Institutional Analysis) (2015b). Common data set. Retrieved from http://www.obia.utah.edu/ia/cds/ 
Phelps, S. F. (2015). The veteran student experience and the academic librarian. Journal of Academic Librarianship, 41(3), 236-240. doi: 10.1016/j.acalib.2015.04.001

Puente, M.A., Gray, L. \& Agnew, S. (2009). The expanding library wall: Outreach to the University of Tennessee's multicultural/international student population. Reference Services Review, 37(1), 30-43. doi: 10.1108/00907320910934977

Remy, C., \& Seaman, P. (2014). Evolving from disability to diversity: How to better serve high-functioning autistic Students. Reference \& User Services Quarterly, 54), 24-28.

Riehle, C. F., \& Witt, M. C. (2009). Librarians in the hall: Instructional outreach in campus residences. College \& Undergraduate Libraries, 16(2-3), 107-121. doi: 10.1080/10691310902958616

Rudin, P. (2008). No fixed address: The evolution of outreach library services on university campuses. The Reference Librarian, 49(1), 55-75. doi: 10.1080/02763870802103761

Saar, M., \& Arthur-Okor, H. (2013). Reference services for the Deaf and hard of hearing. Reference Services Review, 41, 434-452. doi: 10.1108/RSR-12-2012-0083

Samson, S. (2011). Best practices for serving students with disabilities. Reference Services Review, 39, 260-2 doi: $10.1108 / 00907321111135484$

Sojdehei, V. (2009). Boots to books: Helping college student veterans through library outreach and engagement programs. College \& Research Libraries News, 74(10), 537-538.

Swartz, P. S., Carlisle, B. A., \& Uyeki, E. C. (2007). Libraries and student affairs: Partners for student success. Reference Services Review, 35(1), 109-122. doi: 10.1108/00907320710729409

Switzer, A. T. (2008). Redefining diversity: Creating an inclusive academic library through diversity initiatives. College \& Undergraduate Libraries, 15(3), 280-300. doi:

$10.1080 / 10691310802258182$ 
Texas A\&M. (Sept. 10, 2015). Texas A\&M First In The Nation For Serving Veterans, According To New Poll [Press release]. Retrieved from http://www.kbtx.com/news/headlines/Texas-AM-First-InThe-Nation-For-Serving-Veterans-According-To-New-Poll-326332371.html

Veterans Support Center. (2015). Our Veterans. Retrieved from http://veteranscenter.utah.edu/ourveterans.php

Walter, S. (2005). Moving beyond collections: Academic library outreach to multicultural student centers. Reference Services Review, 33(4), 438-458. doi:10.1108/00907320510631562 \#sthash.kjoVBSp4.dpuf 